\title{
Rekrutmen Program Pemagangan ke Jepang: Suatu Tinjauan Program Pemerintah Daerah
}

\author{
Solechan \\ Fakultas Hukum, Universitas Diponegoro \\ solechan@undip.ac.id
}

\begin{abstract}
Apprenticeships can be carried out inside or outside the territory of Indonesia. In Indonesia there are several apprenticeship programs abroad. Apprenticeship abroad is regulated more specifically in the Regulation of the Minister of Manpower and Transmigration of the Republic of Indonesia Number PER. 08 / MEN / V / 2008 concerning Procedures for Licensing and Implementation of Overseas Internships. This study aims to know the recruitment of apprenticeship programs to Japan: a review of government programs. This research is normative legal research. The results of the study found that apprenticeship abroad has been regulated more specifically in the Regulation of the Minister of Manpower and Transmigration of the Republic of Indonesia Number PER. 08 / MEN / V / 2008 concerning Procedures for Licensing and Implementation of Overseas Internships. The regulation is a mandate and guidance on apprenticeship activities abroad.
\end{abstract}

Keywords: Internship, Japan, Government, Employment

\begin{abstract}
Abstrak
Pemagangan dapat dilaksanakan di dalam maupun di luar wilayah Indonesia. Di Indonesia ada beberapa program pemagangan di luar negeri. Pemagangan di luar negeri diatur lebih spesifik dalam Peraturan Menteri Tenaga Kerja dan Transmigrasi Republik Indonesia Nomor PER. 08/MEN/V/2008 tentang Tata Cara Perizinan dan Penyelenggaraan Pemagangan di Luar Negeri. Penelitian ini bertujuan untuk mengatahui rekrutmen program pemagangan ke Jepang: suatu tinjauan program pemerintah. Penelitian ini merupakan penelitian hukum normatif. Hasil penelitian ditemukan bahwa Pemagangan di luar negeri telah diatur lebih spesifik dalam Peraturan Menteri Tenaga Kerja dan Transmigrasi Republik Indonesia Nomor PER. 08/MEN/V/2008 tentang Tata Cara Perizinan dan Penyelenggaraan Pemagangan di Luar Negeri. Peraturan tersebut sebagai mandat dan panduan kegiatan pemagangan diluar negeri.
\end{abstract}

Kata Kunci: Magang, Jepang, Pemerintah, Ketenagakerjaan 


\section{A. Pendahuluan}

Hal-hal mengenai pelatihan kerja diatur dalam Bab V Undang-Undang Nomor 13 Tahun 2003 tentang Ketenagakerjaan. Fungsi dari pelatihan kerja sebagaimana yang tercantum dalam Undang-Undang Ketenagakerjaan adalah untuk membekali, meningkatkan, dan mengembangkan kompetensi kerja guna meningkatkan kemampuan, produktivitas, dan kesejahteraan. Dalam hal ini, yang dimaksud dengan peningkatan kesejahteraan adalah kesejahteraan bagi tenaga kerja yang diperoleh karena terpenuhinya kompetensi kerja melalui pelatihan kerja.

Berdasarkan Pasal 21 Undang-Undang Ketenagakerjaan, pelatihan kerja dapat diselenggarakan dengan sistem pemagangan. Pemagangan adalah bagian dari sistem pelatihan kerja yang diselenggarakan secara terpadu antara pelatihan di lembaga pelatihan dengan bekerja secara langsung di bawah bimbingan dan pengawasan instruktur atau pekerja/buruh yang lebih berpengalaman, dalam proses produksi barang dan/atau jasa di perusahaan, dalam rangka menguasai keterampilan atau keahlian tertentu.

Pemagangan dapat dilaksanakan di dalam maupun di luar wilayah Indonesia. Di Indonesia ada beberapa program pemagangan di luar negeri. Pemagangan di luar negeri diatur lebih spesifik dalam Peraturan Menteri Tenaga Kerja dan Transmigrasi Republik Indonesia Nomor PER. 08/MEN/V/2008 tentang Tata Cara Perizinan dan Penyelenggaraan Pemagangan di Luar Negeri. Peraturan Menteri tersebut merupakan pelaksanaan dari ketentuan Pasal 25 ayat (3) Undang-Undang Nomor 13 Tahun 2003 tentang Ketenagakerjaan. Program pemagangan ke luar negeri di Indonesia selama ini yang dilakukan secara tertib dan telah berjalan secara terus menerus adalah program pemagangan ke Jepang. ${ }^{1}$ Program pemagangan ke Jepang adalah wujud kerjasama antara Kementerian Tenaga Kerja dan Transmigrasi Republik Indonesia dengan IM Japan dalam rangka meningkatkan mutu Sumber Daya Manusia Bangsa Indonesia terutama generasi muda dalam rangka menyongsong Era Globalisasi. Berdasarkan "Sistem Keterampilan" yang dibentuk pemerintah Jepang, telah diberangkatkan ratusan ribu pemagang Indonesia yang direkrut melalui Kementerian Tenaga Kerja dan Transmigrasi untuk mengikuti program magang selama 3 tahun. Sampai saat ini, terdapat dua skema program magang bagi tenaga kerja asing, yaitu Industrial Training Program (ITP) dan

1 Andari Yurikosari, Review Penyelenggaraan Pemagangan Luar Negeri dalam Rangka Penempatan (Studi Mengenai Peraturan Menteri Tenaga Kerja dan Transmigrasi Nomor 08 Tahun 2008), halaman 48. 
Technical Internship Program (TIP). Dalam pelaksanaannya, kombinasi dari skema ITP (maksimum 1 tahun) dan skema TIP (maksimum 2 tahun) merupakan hal yang umum, sehingga secara keseluruhan dapat bekerja maksimum 3 tahun. ${ }^{2}$ Para peserta magang dari tahun ke-1, tahun ke-2 dan tahun ke-3 (3 tahun di Jepang) juga akan menerima gaji/upah setiap bulannya. Bulan pertama (Training Center di Jepang) menerima tunjangan sebesar $¥ 80.000$ bersih, tahun pertama (dari bulan kedua) menerima gaji/upah sekurangkurangnya $¥ 90.000 /$ bulan tunjangan/bersih, tahun kedua menerima gaji/upah sekurangkurangnya $¥ 90.000 /$ bulan, dan tahun ketiga menerima gaji/upah sekurang-kurangnya $¥$ $100.000 /$ bulan.

Program pemagangan merupakan salah satu program latihan kerja pemerintah sebagai upaya menambah keterampilan, wawasan, dan ilmu pengetahuan serta etos kerja. Tujuan dari program pemagangan ini adalah pembinaan sumber daya manusia melalui peningkatan keterampilan dan pengasahan ilmu-ilmu teknik melalui program kerja selama 3 tahun di perusahaan kecil dan menengah di Jepang yang diharapkan juga dapat ikut berperan serta dalam era kompetisi global. Dengan diselenggarakannya program pemagangan ke Jepang, para peserta program pemagangan dapat bekerja sambil belajar. Selain mereka mendapatkan gaji/upah dari pekerjaannya, mereka juga mendapatkan pelajaran dan pengalaman dari pekerjaan mereka karena mereka bekerja di bawah pengawasan dan bimbingan instruktur atau pekerja yang lebih berpengalaman.

Dari aspek teknologi, pemagangan merupakan program untuk meningkatkan kemampunan individu dalam suatu sektor tertentu sehingga tercapai level kemampuan di suatu skop pekerjaan dengan indikasi mampu mempraktikkannya secara individu. ${ }^{3}$ Peserta program nantinya diharapkan mampu membuka lapangan kerja baik untuk dirinya sendiri maupun untuk orang lain. Hal ini dikarenakan setelah menyelesaikan program pemagangan selama 3 (tiga) tahun dengan baik, mereka diharuskan kembali ke Indonesia dengan diberikan tunjangan modal untuk usaha mandiri sebesar $¥ 600.000$.

Pendaftaran calon peserta seleksi program pemagangan ke Jepang dilakukan oleh Tim/Panitia Rekrutmen/Seleksi di Kantor Dinas Tenaga Kerja dan Transmigrasi tingkat Provinsi/Kota/Kabupaten di mana calon peserta berdomisili dan sesuai dengan Kartu Tanda Penduduk (KTP). Pada Pasal 3 Peraturan Daerah Provinsi Jawa Tengah

2 Cholichul Hadi dan Dodik Kurniawan, Potensi dan Problematika KENSHUSEI (Pemagangan Indonesia di Jepang) Menuju Kemandirian, (Surabaya: Pupuk Surabaya, 2010), halaman 13.

${ }^{3}$ Ibid, halaman 12 . 
Nomor 9 Tahun 2016 tentang Pembentukan dan Susunan Perangkat Daerah Provinsi Jawa Tengah berdasarkan Peraturan Gubernur Jawa Tengah Nomor 64 Tahun 2016 tentang Organisasi dan Tata Kerja Dinas Tenaga Kerja dan Transmigrasi Provinsi Jawa Tengah menjelaskan bahwa Dinas Tenaga Kerja dan Transmigrasi merupakan unsur pelaksana urusan pemerintahan bidang tenaga kerja dan bidang transmigrasi yang berkedudukan di bawah dan bertanggung jawab kepada Gubernur melalui Sekretaris Daerah. Dinas Tenaga Kerja dan Transmigrasi mempunyai tugas pokok melaksanakan urusan pemerintahan bidang tenaga kerja dan transmigrasi yang menjadi kewenangan Daerah dan tugas pembantuan yang ditugaskan kepada Daerah. Dalam program pemagangan ke Jepang, Dinas Tenaga Kerja dan Transmigrasi bertindak sebagai lembaga yang berwenang mengatur program pemagangan ke Jepang.

Program Pemagangan ke Jepang ini tidak ada batasan kuota. Jumlah peserta yang mendaftar untuk mengikuti program pemagangan ke Jepang cukup banyak, namun jumlah peserta yang lolos sangatlah sedikit. Berdasarkan latar belakang yang telah dikemukakan, maka perumusan masalah dalam penelitian ini adalah : Bagaimana peran peran pemerintah berkaitan dengan pemagangan dalam Peraturan Gubernur Jawa Tengah Nomor 64 Tahun 2016 tentang Organisasi dan Tata Kerja Dinas Tenaga Kerja dan Transmigrasi Provinsi Jawa Tengah.

\section{B. Pembahasan}

\section{Tenaga Kerja dan Pekerja/Buruh}

Menurut Pasal 1 angka 2 Undang-Undang Nomor 13 Tahun 2003 tentang Ketenagakerjaan, pengertian dari tenaga kerja adalah setiap orang yang mampu melakukan pekerjaan guna menghasilkan barang dan/atau jasa baik untuk memenuhi kebutuhan sendiri maupun untuk masyarakat. Sedangkan menurut Pasal 1 angka 3 Undang-Undang Nomor 13 Tahun 2003 tentang Ketenagakerjaan, memberikan pengertian pekerja/buruh adalah setiap orang yang bekerja dengan menerima upah atau imbalan dalam bentuk lain.

Istilah tenaga kerja digunakan, baik di luar maupun di dalam hubungan kerja, sedangkan pekerja khusus di dalam hubungan kerja. Berarti setiap pekerja sudah pasti tenaga kerja, tetapi setiap tenaga kerja belum tentu pekerja. ${ }^{4}$ Istilah pekerja/buruh muncul sebagai pengganti istilah buruh. Pada zaman kolonial atau

${ }^{4}$ Abdul Khakim, Pengantar Hukum Ketenagakerjaan Indonesia Berdasarkan UndangUndang Nomor 13 Tahun 2003, (Bandung: PT Citra Aditya Bakti, 2003), halaman 3. 
zaman penjajahan Belanda dahulu yang dimaksudkan dengan buruh adalah orangorang pekerja kasar seperti kuli, mandor, tukang, dan lain-lain. Orang-orang ini oleh pemerintah Belanda dahulu disebut dengan blue collar (berkerah biru), sedangkan orang-orang yang mengerjakan pekerjaan "halus" seperti pegawai administrasi yang bisa duduk di meja disebut dengan "white collar" (bekerah putih). Biasanya orangorang yang termasuk golongan ini adalah para bangsawan yang bekerja di kantor dan juga orang-orang Belanda dan Asia Timur lainnya.

Pemerintah Hindia Belanda membedakan antara blue collar dengan white collar ini semata-mata untuk memecah belah golongan Bumiputra, di mana oleh pemerintah Belanda antara white collar dengan blue collar diberikan kedudukan dan status yang berbeda. Orang-orang white collar dikatakannya adalah orang-orang yang terhormat yang pantang melakukan pekerjaan-pekerjaan kasar, sedangkan orang-orang blue collar adalah kuli kasar yang hampir sama kedudukan dengan "budak" yang harus tunduk dan patuh, hormat kepada orang-orang white collar. Di sinilah letak kelicikan penjajah Belanda untuk memecah belah bangsa kita sesuai dengan prinsip "devide et empera"-nya yang terkenal itu.

Pada awalnya sejak diadakan Seminar Hubungan Perburuhan Pancasila pada tahun 1974, istilah buruh direkomendasikan untuk diganti dengan istilah pekerja. Usulan penggantian ini didasari pertimbangan istilah buruh yang sebenarnya merupakan istilah teknis biasa saja, telah berkembang menjadi istilah yang kurang menguntungkan. Mendengar kata buruh orang akan membayangkan sekelompok tenaga kerja dan golongan bawah yang mengandalkan otot. Pekerja administrasi tentu saja tidak mau disebut buruh. Di samping itu, dengan dipengaruhi oleh paham Marxisme, buruh dianggap suatu kelas yang selalu menghancurkan pengusaha/majikan dalam perjuangan. Oleh karena itu, penggunaan kata buruh telah mempunyai motivasi yang kurang baik, hal ini tidak mendorong tumbuh dan berkembangnya suasana kekeluargaan, kegotong-royongan, dan musyawarah untuk mencapai mufakat dalam perusahaan sehingga dirasakan perlu diganti dengan istilah baru. Untuk mendapatkan istilah baru yang sesuai dengan keinginan memang tidak mudah. Oleh karena itu, kita harus kembali dalam Undang-Undang Dasar Negara Republik Indonesia Tahun 1945 yang pada penjelasan Pasal 2 disebutkan, bahwa "yang disebut golongan-golongan ialah badan-badan seperti koperasi, serikat pekerja dan lain-lain badan kolektif”. Jelas di sini Undang-Undang Dasar Negara Republik Indonesia Tahun 1945 menggunakan istilah "pekerja" untuk pengertian buruh. Oleh 
karena itu, disepakati penggunaan kata "pekerja" sebagai kata "buruh" karena mempunyai dasar hukum yang kuat (Hartono Widodo dan Judiantoro, 1992: 7). ${ }^{5}$

Namun kemudian, dengan diundangkannya Undang-Undang Nomor 13 Tahun 2003 tentang Ketenagakerjaan istilah pekerja digantikan dengan istilah buruh sehingga menjadi istilah pekerja/buruh. Menurut Undang-Undang Nomor 13 Tahun 2003 tentang Ketenagakerjaan, pekerja/buruh adalah: "Setiap orang yang bekerja dengan menerima upah atau imbalan dalam bentuk lain" (Pasal 1 angka 3 UndangUndang Nomor 13 Tahun 2003 tentang Ketenagakerjaan).

Berdasarkan tingkat usia pekerja dapat dibedakan menjadi dua yaitu :

a. Anak ialah setiap orang yang masih berusia di bawah umur 18 (delapan belas) tahun.

b. Orang Dewasa ialah orang yang telah berusia 18 (delapan belas) tahun atau lebih.

Jika dilihat dari macam/jenis tenaga kerja berdasarkan keahlian/kemampuan antara terdidik/terlatih dan tidak terdidik/tidak terlatih.

a. Tenaga kerja terdidik

Tenaga kerja terdidik adalah tenaga kerja yang mendapatkan suatu keahlian atau kemahiran pada suatu bidang karena sekolah atau pendidikan formal dan non formal.

b. Tenaga kerja terlatih

Tenaga kerja terlatih adalah tenaga kerja yang memiliki keahlian dalam bidang tertentu yang didapat melalui pengalaman kerja. Tenaga kerja terampil ini dibutuhkan latihan secara berulang-ulang sehingga mampu menguasai pekerjaan tersebut.

c. Tenaga kerja tidak terdidik dan tidak terlatih

Tenaga kerja tidak terdidik dan tidak terlatih adalah tenaga kerja kasar yang hanya mengandalkan tenaga kerja saja.

\section{Pelatihan Kerja}

Yang dimaksud pelatihan kerja adalah keseluruhan kegiatan untuk memberi, memperoleh, meningkatkan, serta mengembangkan potensi kerja, produktivitas, disiplin, sikap, dan etos kerja pada tingkat keterampilan dan keahlian

${ }^{5}$ Zaeni Asyhadie, Hukum Kerja: Hukum Ketenagakerjaan Bidang Hubungan Kerja, (Jakarta: PT RajaGrafindo Persada, 2007), halaman 19-21. 
tertentu sesuai dengan jenjang dan kualifikasi jabatan atau pekerja (Pasal 1 angka 9 Undang-Undang Nomor 13 Tahun 2003 tentang Ketenagakerjaan). Lebih lanjut mengenai pelatihan kerja diatur pada Pasal 9 sampai dengan Pasal 30 UndangUndang Nomor 13 Tahun 2003 tentang Ketenagakerjaan.

Pasal 11 Undang-Undang Nomor 13 Tahun 2003 tentang Ketenagakerjaan menyebutkan bahwa setiap tenaga kerja berhak untuk memperoleh dan/atau meningkatkan dan/atau mengembangkan kompetensi kerja sesuai dengan bakat, minat, dan kemampuannya melalui pelatihan kerja. Dengan demikian, tenaga kerja sebagai pelaku (subjek) pembangunan, sekaligus juga sebagai tujuan pembangunan, berperan meningkatkan produktivitas nasional dan kesejahteraan masyarakat. Berkaitan dengan hal ini tenaga kerja harus diberdayakan, agar mereka memiliki kemampuan dan nilai lebih serta berdaya saing tinggi. Untuk mencapai hal tersebut diperlukan pembinaan secara terarah dan berkelanjutan.

Pelatihan kerja diselenggarakan dan diarahkan untuk membekali, meningkatkan, dan mengembangkan kompetensi kerja guna meningkatkan kemampuan, produktivitas, dan kesejahteraan bagi tenaga kerja. Upaya pembinaan tenaga kerja ditempuh melalui perencanaan dan program ketenagakerjaan, seperti pelatihan, pemagangan dan pelayanan penempatan kerja.

Program pelatihan kerja juga bertujuan menyiapkan tenaga kerja untuk mengisi kesempatan/lowongan kerja. Beberapa hal penting mengenai penyelenggaraan pelatihan kerja yang diatur dalam Undang-Undang Nomor 13 Tahun 2003. ${ }^{6}$

1. Pelatihan kerja dilaksanakan dengan memperhatikan kebutuhan pasar kerja dan dunia usaha, baik di dalam maupun di luar hubungan kerja (Pasal 10 ayat (1)).

2. Pelatihan kerja diselenggarakan berdasarkan program pelatihan yang mengacu pada standar kompetensi kerja (Pasal 10 ayat (2)).

3. Pengusaha bertanggung jawab atas peningkatan dan/atau pengembangan kompetensi pekerjanya melalui pelatihan kerja (Pasal 12 ayat (1)).

4. Setiap pekerja/buruh memiliki kesempatan yang sama untuk mengikuti pelatihan kerja sesuai dengan bidang tugasnya (Pasal 12 ayat (3)).

\footnotetext{
${ }^{6}$ Ibid, halaman 83-86.
} 
5. Pelatihan kerja diselenggarakan oleh lembaga pelatihan kerja pemerintah dan/atau lembaga pelatihan kerja swasta (Pasal 13 ayat (1)). Yang dimaksud pelatihan kerja swasta adalah pelatihan kerja perusahaan.

6. Lembaga pelatihan kerja swasta dapat dibentuk badan hukum Indonesia atau perorangan (Pasal 14 ayat (1)).

7. Lembaga pelatihan kerja swasta wajib memperoleh izin atau mendaftar kepada instansi yang bertanggung jawab di bidang ketenagakerjaan di kabupaten/kota (Pasal 14 ayat (2)).

8. Lembaga pelatihan kerja pemerintah mendaftarkan kegiatannya kepada instansi yang betanggung jawab di bidang ketenagakerjaan kabupaten/kota (Pasal 14 ayat (3)).

9. Penyelenggara pelatihan kerja (Pasal 15) wajib memenuhi persyaratan :
a. Tersedianya tenaga kepelatihan (instruktur);
b. Adanya kurikulum yang sesuai dengan tingkat pelatihan;
c. Tersedianya sarana dan prasarana pelatihan kerja; dan
d. Tersedianya dana bagi kelangsungan kegiatan penyelenggaraan pelatihan kerja.

10. Instansi yang bertanggung jawab di bidang ketenagakerjaan di kabupaten/kota dapat menghentikan sementara pelaksanaan penyelenggaraan pelatihan (Pasal 17 ayat (1)), apabila :
a. Tidak sesuai dengan arah pelatihan kerja seperti ketentuan Pasal 9;
b. Tidak memenuhi persyaratan seperti ketentuan Pasal 15.

11. Penghentian penyelenggaraan pelatihan kerja tersebut disertai alasan dan saran perbaikan, dan berlaku paling lama enam bulan (Pasal 17 ayat (2)).

12. Bila selama enam bulan ternyata penyelenggara pelatihan kerja tidak memenuhi dan melengkapi saran perbaikan, maka dikenakan sanksi penghentian program pelatihan (Pasal 17 ayat (4)).

13. Penyelenggara pelatihan kerja yang tidak menaati dan tetap melaksanakan program pelatihan kerja yang telah dihentikan, dikenakan sanksi pencabutan izin dan pembatalan pendaftaran penyelenggara pelatihan (Pasal 17 ayat (5)).

14. Pelatihan kerja bagi tenaga kerja penyandang cacat dilaksanakan dengan memperhatikan jenis, derajat kecacatan, dan kemampuan tenaga kerja penyandang cacat yang bersangkutan (Pasal 19). 
15. Pelatihan kerja dapat diselenggarakan dengan sistem pemagangan (Pasal 21).

a. Pemagangan dilaksanakan atas dasar perjanjian pemagangan antara peserta dengan pengusaha secara tertulis (Pasal 22 ayat (1)).

b. Perjanjian pemagangan minimal memuat ketentuan hak dan kewajiban antara peserta dengan pengusaha, serta jangka waktu pemagangan (Pasal 22 ayat (2)).

Hak peserta pemagangan, antara lain memperoleh :

- Uang saku dan/atau uang transpor;

- Jaminan sosial tenaga kerja;

- Sertifikat setelah lulus program.

Hak pengusaha, antara lain :

- Hasil kerja/jasa peserta pemagangan;

- Merekrut pemagang sebagai pekerja/buruh bila memenuhi persyaratan.

Kewajiban peserta pemagangan, antara lain :

- Menaati perjanjian pemagangan;

- Mengikuti tata tertib program pemagangan;

- Mengikuti tata tertib perusahaan.

- Kewajiban pengusaha, antara lain :

- Menyediakan uang saku dan/atau uang transpor bagi peserta pemagangan;

- Menyediakan fasilitas pelatihan;

- Menyediakan instruktur;

- Menyediakan perlengkapan keselamatan dan kesehatan kerja.

c. Tanpa adanya perjanjian pemagangan, maka pemagangan dianggap tidak sah dan status peserta berubah menjadi pekerja/buruh perusahaan yang bersangkutan (Pasal 22 ayat (3)).

d. Tenaga kerja yang telah mengikuti program pemagangan berhak atas pengakuan kualifikasi kompetensi kerja di perusahaan atau lembaga sertifikasi (Pasal 23). 
Secara umum pelatihan kerja (Manulang, 1995: 28) terbagi menjadi tiga kelompok kebutuhan ${ }^{7}$ :

a. Kebutuhan latihan untuk bekerja dan hubungan kerja;

b. Kebutuhan latihan untuk bekerja mandiri;

c. Kebutuhan latihan untuk peningkatan bagi yang sudah bekerja (upgrading).

\section{Program dan Target Latihan Kerja}

Pada dasarnya program latihan merupakan lanjutan program pendidikan sekolah, meskipun ada kalanya sebuah latihan dapat diberikan kepada mereka yang tidak pernah bersekolah sama sekali. Sebagai sarana membentuk kemampuan kerja, program ini bertujuan memberikan pengetahuan dan keterampilan kerja. Karena kurikulumnya lebih dititik beratkan pada mengajarkan proses poduksi barang atau jasa, pengetahuan yang diperlukan dalam pekerjaan, serta membentuk sikap efektif dan efisien dalam pekerjaan.

Kita mengenal tiga macam sistem latihan kerja. Pertama latihan institusional atau klasikal yang biasa diberikan oleh lembaga pelatihan kerja kepada satu kelompok atau kelas siswa bersama-sama. Dalam latihan semacam ini semua siswa menerima macam pelajaran atau instruksi yang sama, dan seorang instruktur atau guru pada setiap saat berhadapan dengan satu kelas. Karena pelajaran diberikan di luar lingkungan dan proses kerja yang sebenarnya, maka yang diberikan pada umumnya berupa kejuruan dasar, dan belum benar-benar bersifat khas pekerjaan atau job specific.

Kedua adalah latihan dalam pekerjaan. Di sini siswa diberikan pelajaran dalam lingkungan kerja dan melakukan proses produksi yang sebenarnya dengan dibimbing dan diawasi oleh seorang pekerja senior yang bertindak sebagai instrukturnya. Dalam program yang baik, pelajaran diberikan selama kurun waktu tertentu, secara bertahap mulai dari tugas yang paling sederhana, mudah dan mengandung risiko kecil, sampai tugas yang paling sukar, berat dan mengandung risiko besar. Pada dasarnya tiap-tiap siswa menerima tugas yang berbeda dan seorang instruktur hanya berhadapan dengan seorang siswa. Petunjuk yang diberikan juga sama dengan yang diberikan kepada pekerja bukan siswa. Keterampilan kejuruan yang diberikan dalam latihan semacam ini sudah sesuai

\footnotetext{
${ }^{7}$ Ibid, halaman 87.
} 
dengan tuntutan pekerjaan, baik keterampilan menjalankan proses, menggunakan sarana dan bahan kerja, maupun kemampuan menyesuaikan diri dengan lingkungan fisik dan sosial pekerjaan. Karenanya latihan dan keterampilan yang diterima oleh siswa sudah dapat disebut khas pekerjaan atau job specific.

Ketiga adalah latihan apprenticeship. Dalam program ini kurikulumnya terdiri dari kombinasi atau berkesinambungan antara pelajaran teori dalam kelas dan pelajaran praktik dalam pekerjaan. Pelajaran teori memberikan pengetahuan dasar yang diperlukan dalam pekerjaan. Kemampuan kerja yang dibentuk terdiri dari kejuruan tingkat menengah sampai tingkat tinggi. ${ }^{8}$

Pelatihan kerja berbasis kompetensi harus didukung dengan fasilitas dan sarana, instruktur dan tenaga kepelatihan serta pembiayaan yang sesuai dengan jenis, kemasan dan tingkat program pelatihan yang telah ditetapkan. Pelatihan kerja berbasis kompetensi diselenggarakan di lembaga pelatihan kerja (LPK), baik milik pemerintah, swasta maupun perusahaan. Pelatihan kerja berbasis kompetensi juga dapat diselenggarakan dengan sistem pemagangan. ${ }^{9}$ Pelatihan kerja diselenggarakan dengan prinsip dasar dan kebijakan sebagai berikut :

1. Berorientasi pada kebutuhan pasar kerja dan pengembangan SDM;

2. Berbasis pada kompetensi kerja;

3. Merupakan bagian integral dari pengembangan profesionalisme sepanjang hayat;

4. Diselenggarakan secara berkeadilan dan tidak diskriminatif;

5. Menjadi tanggung jawab bersama antara dunia usaha, pemerintah dan masyarakat.

Pelatihan kerja harus dilihat sebagai kegiatan investasi sumber daya manusia (Human Capital Investment), baik pada tingkat makro maupun tingkat mikro. Oleh karena itu, pelatihan kerja harus direncanakan secara cermat dan dilaksanakan secara efektif dan efisien. Keberhasilan pelatihan kerja tidak hanya diukur dari out-put pelatihan, tetapi juga dari out-come pelatihan. Dalam kaitannya dengan hal ini, pelatihan kerja bagi pencari kerja harus bermuara pada penempatan kerja, sedang

\footnotetext{
${ }^{8}$ Suroto, Strategi Pembangunan dan Perencanaan Kesempatan Kerja, (Yogyakarta: Gadjah Mada University Press, 1992), halaman 347-348.

9 Pedoman Penyelenggaraan Sistem Pelatihan Kerja Nasional di Daerah, (Jakarta, Departemen Tenaga Kerja dan Transmigrasi RI Direktorat Jenderal Pembinaan Pelatihan dan Produktivitas), halaman 10.
} 
pelatihan kerja bagi tenaga kerja yang sudah bekerja harus berdampak pada peningkatan produktivitas kerja.

Pelatihan kerja bagi pencari kerja titik beratnya menjadi tanggung jawab pemerintah, sedang pelatihan kerja bagi pekerja titik beratnya menjadi tanggung jawab perusahaan. Pemerintah (Pusat), Pemerintah Daerah Provinsi maupun Kabupaten/Kota, wajib mengalokasikan biaya yang memadai untuk pelaksanaan pelatihan bagi pencari kerja. Demikian pula perusahaan, juga perlu mengalokasikan biaya yang memadai untuk melatih pekerjannya.

Guna mencapai penyelenggaraan pelatihan yang relevan dengan kebutuhan pasar kerja, efektif dalam mencapai sasaran dan efisien dalam menggunakan sumber daya, perlu adanya "Perencanaan Pelatihan Kerja" pada tingkat nasional, daerah provinsi maupun daerah kabupaten/kota. Perencanaan pelatihan kerja dimaksud untuk jangka waktu minimal 5 (lima) tahun dengan memuat antara lain :

1. Bidang, jenis dan kualifikasi pelatihan yang diperlukan sesuai dengan kebutuhan pasar kerja serta peningkatan produktivitas pada tingkat kabupaten/kota, provinsi, nasional, dan pasar kerja global;

2. Jumlah kebutuhan pelatihan pada setiap bidang, jenis dan kualifikasi pelatihan;

3. Rencana dan program untuk memenuhi kebutuhan pelatihan sebagaimana dimaksud butir 1 dan 2;

4. Rencana biaya yang diperlukan untuk melaksanakan rencana dan program tersebut butir 3 .

Pelatihan kerja dapat diselenggarakan oleh pemerintah, swasta dan atau perusahaan. Pelatihan kerja yang diselenggarakan oleh swasta wajib mendapatkan perijinan dari instansi yang bertanggung jawab di bidang ketenagakerjaan di tingkat kabupaten/kota. Sedang pelatihan kerja yang diselenggarakan oleh pemerintah atau perusahan, tidak perlu perijinan, tetapi harus terdaftar di instansi yang sama. Tata cara pengajuan dan pemberian perijinan atau pendaftaran penyelenggaraan pelatihan dimaksud mengacu pada Peraturan Menteri Tenaga Kerja dan Transmigrasi R.I. No. PER17/MEN/VI/2007 tentang Tata Cara Perijinan dan Pendaftaran Lembaga Pelatihan Kerja.

Penyelenggaraan pelatihan kerja harus didukung dengan sarana dan prasarana yang memenuhi persyaratan untuk menjamin tercapainya standar 
kompetensi kerja. Standar persyaratan fasilitas dan sarana pelatihan tersebut mengacu pada Peraturan Menteri Tenaga Kerja dan Transmigrasi tentang Standar Minimal Fasilitas dan Sarana Pelatihan Kerja. Penyelenggaraan pelatihan kerja juga harus didukung dengan tenaga kepelatihan yang memenuhi persyaratan kualifikasi kompetensi sesuai dengan bidang tugasnya. Kualifikasi kompetensi tersebut mencakup kompetensi teknis, pengetahuan dan sikap kerja. Standar kualifikasi tenaga kepelatihan yang dimaksud mengacu pada Peraturan Menteri Tenaga Kerja dan Transmigrasi tentang Standar Minimal Kualifikasi Tenaga Kepelatihan. ${ }^{10}$

\section{Lembaga Pelatihan Kerja}

Lembaga Pelatihan Kerja yang selanjutnya disingkat LPK adalah instansi pemerintah, badan hukum atau perorangan yang memenuhi persyaratan untuk menyelenggarakan pelatihan kerja.

Pelatihan kerja diselenggarakan oleh :

a. LPK Swasta;

b. LPK Pemerintah; atau

c. LPK Perusahaan.

Pembagian tugas dan tanggung jawab penyelenggaraan pelatihan kerja oleh LPK Pemerintah, LPK Swasta dan LK Perusahaan, diatur sebagai berikut $^{11}$ :

1. LPK Pemerintah, titik beratnya menyelenggarakan pelatihan pada bidang, jenis dan atau kualifikasi pelatihan kerja tertentu yang sangat diperlukan oleh pasar kerja, tetapi belum mampu diselenggarakan oleh masyarakat;

2. LPK Swasta, menyelenggarakan pelatihan kerja pada bidang, jenis dan atau kualifikasi tertentu yang dibutuhkan pasar kerja, yang mampu diselenggarakan dan dibiayai oleh masyarakat;

3. LPK Perusahaan, titik beratnya menyelenggarakan pelatihan kerja pada bidang, jenis dan atau kualifikasi tertentu yang tidak atau belum dapat diselenggarakan oleh pemerintah atau masyarakat, untuk kepentingan perusahaan sendiri.

LPK Swasta yang menyelenggarakan pelatihan kerja bagi masyarakat umum wajib memiliki izin yang diterbitkan oleh kepala dinas kabupaten/kota.

${ }^{10}$ Ibid, halaman 20-22.

${ }^{11}$ Ibid, halaman 21-22. 
Izin diberikan nomor registrasi LPK oleh kepala dinas kabupaten/kota sesuai dengan Peraturan Menteri Dalam Negeri yang mengatur mengenai kode dan data wilayah administrasi pemerintahan. Izin LPK tersebut, berlaku selama LPK aktif menyelenggarakan pelatihan kerja.

Untuk mengetahui sejauh mana suatu LPK telah mampu menyelenggarakan pelatihan berbasis kompetensi, dilakukan akreditasi. Akreditasi adalah proses pemberian pengakuan formal yang menyatakan bahwa suatu LPK telah mampu melakukan kegiatan pelatihan kerja berbasis kompetensi, untuk jenis, kemasan dan tingkat program pelatihan tertentu. Sesuai dengan Undang-Undang Nomor 13 Tahun 2003 tentang Ketenagakerjaan dan Peraturan Pemerintah Nomor 31 Tahun 2006 tentang Sistem Pelatihan Kerja Nasional, akreditasi LPK bersifat sukarela dan dilaksanakan oleh Lembaga Akreditasi Lembaga Pelatihan Kerja (LA-LPK) yang independen yang dibentuk dengan Peraturan Menteri.

Peserta pelatihan yang telah berhasil menyelesaikan program pelatihan berbasis kompetensi, berhak mendapat Sertifikat Pelatihan. Sertifikat Pelatihan diterbitkan oleh LPK. Sertifikat Pelatihan berbeda dengan Sertifikat Kompetensi. Sertifikat Pelatihan adalah tanda bukti resmi bahwa seseorang telah berhasil menyelesaikan suatu program pelatihan kerja tertentu. Sedang Sertifikat Kompetensi adalah tanda bukti bahwa seseorang telah menguasai kompetensi kerja tertentu sesuai dengan SKKNI. Sertifikat Kompetensi diterbitkan oleh Lembaga Sertifikasi Profesi (LSP) yang telah mendapatkan lisensi dari Badan Nasional Sertifikasi Profesi (BNSP). Peserta pelatihan yang telah berhasil menyelesaikan program pelatihan dapat mengakses Sertifikat Kompetensi melalui Sertifikasi Kompetensi. ${ }^{12}$

\section{Pemagangan}

Selain dengan lembaga pelatihan kerja maka pelatihan kerja dapat diselenggarakan dengan sistem pemagangan. Menteri Tenaga Kerja dapat mewajibkan kepada perusahaan yang memenuhi persyaratan untuk melaksanakan program pemagangan. Magang sebagai satuan pendidikan luar sekolah, diperhitungkan mampu meningkatkan kemampuan, keterampilan dan perubahan sikap warga belajar sebagai pemagang, terutama sikap yang berkaitan dengan nilai-nilai kemandirian, dan dapat

${ }^{12}$ Ibid, halaman 10-11. 
dijadikan modal bagi peningkatan kualitas hidup. Selain itu, magang dapat pula dilakukan secara individual ataupun kolektif, terutama yang berkaitan dengan nilainilai (keyakinan agama yang dianutnya). Dengan proses ini memungkinkan seseorang belajar mengembangkan diri secara optimal aspek fisik, intelektual efektif dan spiritual secara seimbang, baik secara personal, sosial, maupun profesional (Trisnamansyah, 1992).

Iklim belajar yang terjadi pada proses pembelajaran magang berbeda dengan yang terjadi pada program dan atau satuan pendidikan luar sekolah lainnya. Pada proses pembelajaran magang menggunakan pendekatan yang memadukan antara belajar dan latihan sambil bekerja serta mendapatkan upah kerja diri keterampilan yang dipelajari dan dipraktikkannya. ${ }^{13}$

Program pembelajaran magang pada tingkat implementasi kurikulum dan pengelolaan pembelajarannya sangat dipengaruhi oleh nilai-nilai budaya belaja bekerja yang berkembang di tengah-tengah masyarakat di mana kegiatan tersebut diselenggarakan. Learning by doing, learning and doin atau learning by watching and doing sebagai proses pembelajaran yang telah terlembagakan dan berlangsung secara turun-temurun di tengah-tengah masyarakat, memiliki dimensi mendasar dalam membentuk watak dan kebiasaan melalui transfer pengetahuan, keterampilan dan pengalaman. $^{14}$

Menurut Greene dalam bukunya yang berjudul "Belajar Tak Hanya di Sekolah", magang adalah seorang pemula yang mempelajari suatu keahlian. Menjadi staf magang adalah langkah besar untuk mengejar jalur karier tertentu. Saat magang, kita menerima pelatihan kerja dari seorang penyelia berpengalaman yang ahli dalam pekerjaan atau profesi tertentu. Kita dianggap sebagai pekerja paruh waktu dan dibayar atas pekerjaan kita. Magang reguler yang disponsori oleh Departemen Tenaga Kerja, bersama dengan pemerintah daerah dan berbagai agen tenaga kerja terdekat, biasanya mengharuskan peserta untuk berusia di atas 18 tahun. Akan tetapi, magang untuk pemula (juga disponsori oleh Departemen Tenaga Kerja) memiliki syarat yang berbeda. Sesuai dengan hukum perlindungan anak, harus berusia 16 tahun sebelum

13 Mustofa Kamil, Model Pembelajaran Magang Bagi Peningkatan Kemandirian Warga Belajar: Suatu Pendekatan Baru, (Dinamika Pendidikan No. 01/Tahun X Maret 2003), halaman 20.

${ }^{14} \mathrm{Ibid}$, halaman 12. 
bisa bergabung dalam program magang pemula. Sebagian siswa magang pemula memulai program mereka di kelas 11 sekolah menengah. ${ }^{15}$

Pemberi kerja yang menyewa tenaga magang mendapat keuntungan sebab berkesempatan merekrut dan melatih orang-orang muda untuk menjadi pekerja terampil masa depan dan meneruskan keahlian dari satu generasi ke generasi berikutnya. Para pemberi kerja ini juga berkesempatan mengenali berbagai keahlian yang diperlukan untuk pekerjaan tertentu, menentukan jenis kelas praktik yang mungkin diperlukan, dan memastikan hanya orang-orang terlatihlah yang memasuki bidang pekerjaan mereka. Selain itu, banyak pemberi kerja dan penyelia yang menyukai ide untuk mengajari remaja yang antusias serta "memberikan sesuatu" bagi masyarakat pekerja (terutama bila mereka dulunya pernah magang).

Magang adalah cara yang menarik untuk memperoleh keahlian yang tidak didapatkan dalam ruang kelas. Magang juga menyediakan ${ }^{16}$ :

- pengalaman praktis

- pelatihan kerja

- pengetahuan teknis

- kesempatan kerja secara langsung dengan orang dewasa yang bisa menjelaskan secara mendalam beragam konsep

- bimbingan jangka panjang dari seorang ahli

- koneksi dengan pekerja dewasa yang memiliki keahlian

- menjiwai sebuah lingkungan kerja

- nilai jual yang lebih tinggi saat memasuki dunia kerja

- kesempatan melihat "kehidupan nyata" yang sesungguhnya

- jalur untuk menghubungkan sekolah dan pekerjaan

- gaji (upah bahkan bisa meningkat seiring kemajuan dalam magang tersebut)

Pemagangan dilaksanakan atas dasar perjanjian pemagangan antara peserta dengan pengusaha yang dibuat secara tertulis, dengan sekurang-kurangnya memuat ketentuan hak dan kewajiban peserta dan pengusaha serta jangka waktu pemagangan.

${ }^{15}$ Rebecca Greene, Belajar Tak Hanya di Sekolah (Edisi Terjemahan Bahasa Indonesia), (Penerbit Erlangga, 2006), halaman 154-155.

${ }^{16} \mathrm{Ibid}$, halaman 156. 
Pemagangan yang diselenggarakan tidak melalui perjanjian tertulis, pemagangan dianggap tidak sah dan status peserta berubah menjadi pekerja/buruh perusahaan yang bersangkutan. Pemagangan dapat dilaksanakan di perusahaan sendiri atau di tempat penyelenggaraan pelatihan kerja, atau perusahaan lain, baik di dalam maupun di luar wilayah Indonesia. Pemagangan yang dilakukan di luar Indonesia wajib mendapatkan izin dari Menteri Tenaga Kerja atau pejabat yang ditunjuk.

Penyelenggaraan pemagangan di luar wilayah Indonesia harus memperhatikan:

a. harkat dan martabat bangsa Indonesia;

b. penguasaan kompetensi yang lebih tinggi;

c. perlindungan dan kesejahteraan peserta pemagangan, termasuk melaksanakan ibadahnya.

Menteri atau pejabat yang ditunjuk dapat menghentikan pelaksanaan pemagangan di luar wilayah Indonesia bila di dalam pelaksanaannya ternyata tidak sesuai dengan ketentuan tentang penyelenggaraan pemagangan di luar Indonesia tersebut di atas. ${ }^{17}$

Program pemagangan ke luar negeri di Indonesia selama ini yang dilakukan secara tertib dan telah berjalan secara terus menerus adalah program pemagangan ke Jepang. Program pemagangan ke Jepang ini telah berlangsung selama bertahun-tahun dan didukung penuh oleh Pemerintah Jepang dan Pemerintah Indonesia. Program Pemagangan ke Jepang bersifat apprecentice oleh karena peserta magang diikutsertakan ke dalam perusahaan-perusahaan terutama yang bergerak di bidang industri dengan berbagai peserta dari negara-negara lain pula. ${ }^{18}$

\section{Simpulan}

Pemagangan dapat dilaksanakan di dalam maupun di luar wilayah Indonesia. Di Indonesia ada beberapa program pemagangan di luar negeri. Pemagangan di luar negeri diatur lebih spesifik dalam Peraturan Menteri Tenaga Kerja dan Transmigrasi Republik Indonesia Nomor PER. 08/MEN/V/2008 tentang Tata Cara Perizinan dan Penyelenggaraan Pemagangan di Luar Negeri. Pemagangan di luar negeri telah diatur

${ }^{17}$ Hardijan Rusli, Hukum Ketenagakerjaan 2003, (Jakarta: Ghalia Indonesia, 2004), halaman 29-30.

${ }^{18}$ Andari Yurikosari, Op.cit. halaman 48. 
lebih spesifik dalam Peraturan Menteri Tenaga Kerja dan Transmigrasi Republik Indonesia Nomor PER. 08/MEN/V/2008 tentang Tata Cara Perizinan dan Penyelenggaraan Pemagangan di Luar Negeri. Peraturan tersebut sebagai mandat dan panduan kegiatan pemagangan diluar negeri.

\section{Daftar Pustaka}

Asyhadie, Zaeni, Hukum Kerja: Hukum Ketenagakerjaan BidangHubungan Kerja, (Jakarta: PT RajaGrafindo Persada, 2007).

Danim, Sudarwan, Menjadi Peneliti Kualitatif, (Bandung: CV Pustaka Setia, 2002).

Greene, Rebecca, Belajar Tak Hanya di Sekolah, (Penerbit Erlangga, 2006).

Hadi, Cholicul dan Dodik Kurniawan, Potensi dan Problematika KENSHUSEI (Pemagangan Indonesia di Jepang) Menuju Kemandirian, (Surabaya: Pupuk Surabaya, 2010).

Joko Pitoyo, Agus, Pemagangan Luar Negeri Tenaga Kerja: Proses, Pendapatan dan Alih Teknologi.

Kamil, Mustofa, Model Pembelajaran Magang Bagi Peningkatan Kemandirian Warga Belajar: Suatu Pendekatan Baru, (Dinamika Pendidikan No. 01/Tahun X Maret 2003).

Khakim, Abdul, Pengantar Hukum Ketenagakerjaan Indonesia Berdasarkan UndangUndang Nomor 13 Tahun 2003, (Bandung: PT Citra Aditya Bakti, 2003).

Muhammad, Abdulkadir, Hukum dan Penelitian Hukum, (Bandung: PT Citra Aditya Bakti, 2004).

Narbuko, Kholid dan Abu Achmadi, Metodologi Penelitian,(Jakarta: PT Bumi Aksara, 2002).

Pedoman Penyelenggaraan Sistem Pelatihan Kerja Nasional di Daerah, (Jakarta, Departemen Tenaga Kerja dan Transmigrasi RI Direktorat Jenderal Pembinaan Pelatihan dan Produktivitas).

Peraturan Daerah Provinsi Jawa Tengah Nomor 9 Tahun 2016 tentang Pembentukan dan Susunan Perangkat Daerah Provinsi Jawa Tengah

Peraturan Gubernur Jawa Tengah Nomor 64 Tahun 2016 tentang Organisasi dan Tata Kerja Dinas Tenaga Kerja dan Transmigrasi Provinsi Jawa Tengah

Peraturan Menteri Ketenagakerjaan Republik Indonesia Nomor 17 Tahun 2016 tentang Tata Cara Perizinan dan Pendaftaran Lembaga Pelatihan Kerja

Peraturan Menteri Tenaga Kerja dan Transmigrasi Republik Indonesia Nomor PER. 08/MEN/V/2008 tentang Tata Cara Perizinan dan Penyelenggaraan Pemagangan di Luar Negeri

Rusli, Hardijan, Hukum Ketenagakerjaan 2003, (Jakarta: Ghalia Indonesia, 2004).

Soemitro, Ronny Hanitijo, Metodologi Penelitian Hukum dan Jurimetri, (Jakarta: Ghalia Indonesia, 1990).

Suroto, Strategi Pembangunan dan Perencanaan Kesempatan Kerja, (Yogyakarta: Gadjah Mada University Press, 1992). 
Suyono, Tinjauan Yuridis Peran LPK Hinomaru dalam Pelaksanaan Rekruitmen Magang ke Jepang menurut Peraturan Permen No.08/Men/V/2008 di Kabupaten Sragen. Tenaga Kerja dan Transmigrasi Nomor 08 Tahun 2008).

Undang-Undang Dasar Negara Republik Indonesia Tahun 1945

Undang-Undang Nomor 13 Tahun 2003 tentang Ketenagakerjaan

Yurikosari, Andari, Review Penyelenggaraan Pemagangan Luar Negeri dalam Rangka Penempatan (Studi Mengenai Peraturan Menteri 